\title{
CONTRACTUAL EXEMPTION FROM LIABILITY FOR NEGLIGENCE
}

The attempts of parties to relieve themselves by contract from liability in the event that they are negligent in the performance of their duties under the contract have met with varying success. Section 3513 of the California Civil Code states: ${ }^{1}$

Any one may waive the advantage of a law intended solely for his benefit. But a law established for a public reason cannot be contravened by a private agreement.

Thus, whenever the party relying upon the exculpatory clause owes a duty of service to the public, the contract is invalidated as being contrary to public policy. ${ }^{2}$ Furthermore, the courts have gone beyond inquiry into the question of public duty to an examination of the social and economic relationship of the contracting parties. ${ }^{3}$ Thus, through the techniques of voiding such contracts by reason of public policy and of strict construction of the exculpatory clause, ${ }^{4}$ the courts have evidenced a deep-seated reluctance to recognize such agreements which are intended to relieve the party with superior bargaiming power from his duty of ordinary care.

In the recent case of Bisso v. Inland Waterways Corporation ${ }^{5}$ the United States Supreme Court was called upon to decide whether a tugboat might contract away its liability for negligence resulting in damage to its tow. The findings revealed that the Bisso, the barge which was being towed, collided with a bridge pier and sank as a result of the negligent towage by those operating the tugboat Cairo. ${ }^{6}$ One clause in the towage contract provided that the towing movement should be done "at the sole risk" of the barge with the tug being relieved for any loss or damage to the tow, "however occurring"; while another clause specified that the masters, crews, and employees of the tugboat should "in the performance of said

${ }^{1}$ In addition the reader's attention is directed to $C_{A L}$. CIV. CoDE $\$ \$ 1598,1667$ and 1668 which in part state that contracts to exempt anyone from responsibility for his negligent violation of law are against public policy, unlawful, and void. These statutes do not in themselves solve the problem of exculpation, for it still must be determined whether there has been a "violation of law." See Werner v. Knoll, 89 Cal. App.2d 474, 201 P.2d 45 (1948). It is to this end that the courts look in deciding the question of public policy.

2 California Powder Works v. Atlantic \& Pacific R.R. Co., 113 Cal. 329, 336, 45 Pac. 691 , 693 (1896) (by implication). See also RestaTEMEENT, Contracts $\$ 575(1)$ (b) (1932). The question of whether the entire contract or merely the exculpatory clause is invalidated by reason of public policy is not within the scope of this comment. The terms "contract" and "clause" are treated as synonymous for the purposes of this discussion.

3 The courts, for the sake of convenience, uniformity, and certainty, analyze the relative bargaining position of the typical members of the class rather than the particular parties to the suit.

4 See Dieterle v. Bekin, 143 Cal. 683, 77 Pac. 664 (1904), where the stipulation against liability for loss by fire was not construed as excusing the bailee from the exercise of ordinary care to protect the property from fire. See also Gross v. General Inv. Co., 194 Mimn. 23, 259 N.W. 557 (1935); Langford v. Nevin, 117 Tex. 130, 298 S.W. 536 (1927).

5349 U.S. 85 (1955).

${ }^{6}$ At the time of the accident, the Bisso had no motive power, steering apparatus, officers or crew. Its movenrents were entirely controlled by the tug. 
service, become and be the servants" of the barge Bisso. ${ }^{7}$ The majority of the Court, relying on precedent in other tugboat cases $^{8}$ and on analogies to other fields, firmly held that the exemption clause was invalid as against public policy and that the second clause, as a mere device to avoid liability, was equally unenforceable. ${ }^{9}$ The Court listed as its reasons for this rule: (1) the discouraging of negligence by inflicting damages upon wrongdoers, and (2) the protection of consumers of goods and services from harsh contracts forced upon them because of their inferior bargaiming position. ${ }^{10}$ Although the Bisso case arose in admiralty, the law set forth in the case is not unique to admiralty. In fact, the principal case quite definitely is in accord with exculpatory contract cases in other fields. This is clear from the fact that the Court alluded to cases arising in other fields for support in reaching its conclusion.

\section{Exculpation and Mutual Assent}

The determination of the validity of contracts exempting a party from liability for negligence is closely allied to the basic theory of mutual assent. Indeed, the public policy which the Court utilizes in ruling the contract invalid appears to be contractual in origin and purpose. The courts, therefore, first analyze whether the exculpation is part of the agreement between the two parties. If the injured party did not know of the release provision and a reasonable person in his position would not have known of it, then clearly he has not in fact assented to the clause; and the waiver will fail for want of mutual assent. ${ }^{11}$ The small print has not been brought to his

7 Bisso v. Inland Waterways Corporation, 114 F. Supp. 713, 716 (E.D.La. 1953), aff'd, 211 F.2d 401 (4th Cir. 1954), rev'd, 349 U.S. 85 (1955). It is interesting to note that should the second clause be upheld, the corporation would be relieved of liability though the individual employees of the corporation, who by this clause become the employees of the tow, would be liable for their negligence since a master inay recover from his servants for damages resulting from their torts.

${ }^{8}$ The Wash Gray, 277 U.S. 66 (1927), The Steamer Syracuse, 79 U.S. (12 Wall.) 167 (1870), and numerous lower court decisions illustrated a definite judicial hostility toward such contracts in the towage field.

9 The holding in the Bisso case was held to apply in Boston Metals Company v. The S/S Winding Gulf, 349 U.S. 122 (1955), so that the owner of a tow was not hable to a third vessel for the neghigence of the tugboat's servants despite the contract provision that employees of the tug were to be deemed servants of the tow during the towage operation. A more satisfactory explanation for denying recovery, as stated in Justice Frankfurter's concurring opinion (id. at 127 ), is that even assuming the contract's validity, the contracting parties did not intend to give the plaintiff, a stranger to the transaction, any right to recover as a third party beneficiary.

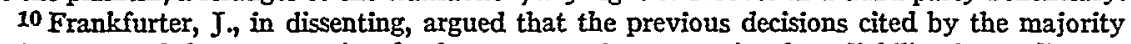
neerely construed the contracts involved as not covering exemption from liability for negligence. He stated that there was no overriding public pohicy involved nor was there any showing of unfair bargaining position. Thus, in his opinion, the Court should not restrict the area of full bargaining between the parties but should rather allow the clauses to take their clearly intended effect.

${ }_{11}$ Agricultural Ins. Co. v. Constantine, 144 Ohio St. 275, 58 N.E.2d 658 (1944) ; Dodge v. Nashville, C. \& St. L. Ry. Co., 142 Tenn. 20, 215 S.W. 274 (1919). Cf. Raynale v. Yellow Cab Co., 115 Cal. App. 90, 300 Pac. 991 (1931); Restatendent, Contracts $\$ 70$ (1932). The California law on this subject is in a fairly confused state. In Curtis v. United Transfer Co., 167 Cal. 112, 138 Pac. 726 (1914), the court lield that the mere taking and retention of a shipping receipt did not of itself amount to assent in the absence of knowledge of the exculpatory pro- 
knowledge and he will not be estopped from asserting that the contract did not cover exemption from liability for negligence. ${ }^{12}$ In many instances, however, as in the Bisso case, the party is aware of the contents of the contract and assents to them simply because lie is not in a position to argue over them. It is here that the courts will point to the unequal bargaining position of the parties and hold that the contract is invalid. ${ }^{13}$ Frequently the courts will specify a policy against encouraging negligence as an additional reason for invalidation. This is never given as a sole ground for voiding the contract; and where the parties are dealing on an equal basis it will not be invoked by the courts. It is rather the policy against liarsh contracts which is called forth in aid of the individual who has not freely assented to the exculpatory clause. ${ }^{14}$

In the leading case of New York Central Railroad Co. v. Lockwood ${ }^{15}$ the Court, in lolding that a common carrier could not contract away its liability for negligence, stated that if the passenger liad any real freedom of choice-a reasonable alternative - and if the carrier were not charged with a public duty, it could more reasonably be said that the contract was simply the affair of the immediate parties and thus a valid agreement. The monopolistic or quasi-monopolistic position of the railroad enabling it to dictate the terms of the contract to carry passengers or goods is sufficient reason to divest the transaction of validity. ${ }^{10}$ The need for the particular service by the contracting party, the impossibility or difficulty in obtaining the service elsewhere, and the fact that the exculpatory clause is the condition upon which the individual procures the service are several of the salient factors to which the courts look in determining the validity of the contract. Where the individual is on such unequal footing that lie lias little or no choice regarding the party with whom and under what terms lie may contract, it would seem a travesty to speak of mutual assent. ${ }^{17}$ Further-

vision. Cunningham v. Int. Com. of Y.M.C.A., 51 Cal. App. 487, 197 Pac. 140 (1921), stated, on the other hand, that the bailor was bound by the contents of the storage check regardless of whether he had read them or not; while in U Drive \& Tour, Ltd. v. System Auto Parks, Ltd., 28 Cal. App.2d 782, 71 P.2d 354 (App. Dep't 1937), the court held that although the driver's attention was not cailed to the stipulation on the parking lot stub, nevertheless he had accepted the ticket without objection and was thus bound by its terms. Inasmuch as CAL. CIV. CODE $\$ 2176$ expressly requires knowledge for mutual assent in case of bills of lading, it is submitted that knowledge clearly should be essential in those situations where the paper is ostensibly given for the purpose of identification.

12 The Majestic, 166 U.S. 375 (1897) ; Maynard v. James, 109 Conn. 365, 146 Atl. 614 (1929) ; Jones v. Great Northern Ry. Co., 68 Mont. 231, 217 Pac. 673 (1923).

13 New York Central Railroad Co. v. Lockwood, 84 U.S. (17 Wall.) 357 (1873).

14 This is cogently illustrated in the Bisso case by the sharp divergence in opinion between Justices Black and Frankfurter as to the existence of and potential for monopoly in the tug industry. Furthermore, Douglas, J., in concurring with the majority, plainly states that he does not know enough about the economics of the situation to change what he considers to be the established rule.

1584 U.S. (17 Wall.) 357 (1873).

10 See Annot, 175 A.L.R. 8, 18-19 (1948); Note, 8 U. Fra. L. REv. 109 (1955).

17 See Goddard, Outinnes of the Law of BarmMents and Carriers, $\$ 260$ (2d ed. 1928). Cf. Oswald v. City of El Centro, 211 Cal. 45, 292 Pac. 1073 (1930); 5 Wurtrston, Contracts § 1608 (rev. ed. 1937). 
more, where the party owes a duty of service to the public, as in the case of the common carrier, it may readily be argued that the public has not assented to the exculpatory clause. In Califorma this situation would seem to fall squarely within the spirit of Civil Code section 3513 .

\section{Exculpation in Common Carrier Contracts}

The rule of New York Central Railroad Co.v. Lockwood is now universally upheld in the United States, ${ }^{18}$ so that a contract exempting a common carrier fron hability for negligence of itself or its servants in the carriage of goods and passengers for hire is invalid as being against public policy. ${ }^{19}$ The carrier nuay, however, gain a measure of protection through devices which artificially reduce the great inequality existing between the carrier and the individual so as to give the latter some choice as to the contract terms. Thus, a special contract in which the charges are graduated according to the value of the property as fixed by the shipper is a valid means of limiting damages in advance. ${ }^{20}$ The shipper has the privilege of securing full coverage by paying the stipulated charge for such protection. If he does not reveal the value of his goods, the carrier may set a definite himit to its liability; and the shipper will be estopped from claiming that they are of greater value than this set limit. ${ }^{21}$ This may be done by public notice which is brought to the knowledge of the shipper and is expressly or impliedly assented to by him. ${ }^{22}$ In this manner the carrier may make a reasonable charge for the additional risk ${ }^{23}$ and take the necessary precautions to insure the safety of the goods. ${ }^{24}$

\footnotetext{
189 Ax. JuR., Carriers \$ 739 (1937).

19 See, e.g., Franklin v. Southern Pacific Co., 203 Cal. 680, 265 Pac. 936 (1928); Nervius v. Chicago, St.P. \& M. Ry. Co., 124 Wis. 313, 102 N.W. 489 (1905). Where no state statute or constitution provides to the contrary, the carrier may enter into a contract with the shipper releasing it from its common law strict liability as an insurer. American Fruit Distributors v. Hines, 55 Cal. App. 377, 203 Pac. 821 (1921). Cf. CAL. CIv. Code $\$ 2174$ providing that the obligations of a common carrier may be limited by special contract. The carrier by Car. Crv. CODE $\$ 2175$ may not contract away its liability for the gross negligence, fraud, or willful wrong of itself or its servants.

20 Franklin v. Southern Pacific Co., 203 Cal. 680, 265 Pac. 936 (1928).

21 Hart v. Pennsylvania Railroad Co., 112 U.S. 331 (1884); Pierce v. Southern Pacific Co., 120 Cal. 156, 47 Pac. 874, 52 Pac. 302 (1898); see Restatenent, Contracts \$575(2) (1932). Contre, Everett v. Norfolk \& S. R. Co., 138 N.C. 68, 50 S.E. 557 (1905).

22 When the shipper accepts a bill of lading upon delivering the goods to the carrier, he is conclusively presumed, in the abseuce of fraud, to have assented to the terms and conditions written or printed upon it. Greenwald v. Barrett, 199 N.Y. 170, 92 N.E. 220 (1910) ; Ballou v. Earle, 17 R.I. 441, 22 Atl. 1113 (1891). In California this presumption will not arise unless the shipper has knowledge of the terms of the instrument. CaL. Crv. Code $\$ 2176$; Curtis v. United Transfer Co., 167 Cal. 112, 138 Pac. 726 (1914).

${ }_{23}$ Such contracts must be supported by consideration; and where the maximum rate allowed by law is charged, the contract limiting liability will fail for lack of consideration. Union Pacific Railroad Co. v. Burke, 255 U.S. 317 (1921) ; Hubbard v. Matson Nav. Co., 34 Cal. App.2d 475, 93 P.2d 846 (1939); McFadden v. Missouri Pacific Railway Co., 92 Mo. 343, 4 S.W. 689 (1887).

24 It lias been held that $C_{A x}$. Crv. CoDE $\$ 2175$ does not invalidate a contract limiting liability to an agreed valuation where the carrier has been guilty of gross neghigence. Donlon Brothers v. Southern Pacific Co., 151 Cal. 763, 91 Pac. 603 (1907).
} 
In England a clause totally exempting the carrier's liability for personal injury is valid if at the same time the individual is given the option of a contract not containing the exculpatory clause at a reasonable increase in rate. ${ }^{25}$ This device is generally not allowed by the American courts; and as long as the passenger has given some consideration for the carriage, the attempt at complete exemption will be held contrary to public policy. ${ }^{26}$

If the passenger is travehing on a free pass, the majority of the courts uphold the exemption clause. ${ }^{27}$ The carrier is under no duty to carry the gratuitous passenger and certainly the coercive element is not present, for the individual inay secure full protection simply by paying the ordinary fare. ${ }^{28}$ In such a case the activity carried on by the carrier is the same as in its usual course of business; but since the passenger is carried purely as a favor, social policy favors the validation of the release contract.

Where the dealing is between connectuig carriers, which are in many respects treated as economic equals, the policy in favor of freedom of contract will prevail and the exculpatory clause held to be valid. ${ }^{20}$ The decision in the Bisso case would appear to be contrary to this since two carriers were involved. But it may be distinguished on the basis of the majority's strong fear of the monopoly potential of the tug industry and the hard bargains which would be exacted should an opposite result be reached.

When the railroad is not acting in discharge of its priniary duty to the public, the individual who chooses to enter into a contractual relationship is not under a disadvantage; and the stipulation against liability for negligence is not repugnant to public policy. Thus, where the railroad leases property along its right of way, ${ }^{30}$ where it contracts to put in side tracks

25 Penton v. Southern Railway, [1931] 2 K.B. 103 (reduced fare return ticket); Thompson v. London, Midland \& Scottish Railway Co., [1930] 1 K.B. 41 (C.A.) (excursion ticket costing one half the ordinary fare).

26 Walther v. Southern Pacific Co., 159 Cal. 769, 116 Pac. 51 (1911) (dictum) ; Pittsburgh, C., C. \& St. L. Ry. Co. v. Higgs, 165 Ind. 694, 76 N.E. 299 (1905) ; Alexander v. St. LouisSan Francisco Ry. Co., 221 Mo. App. 271, 2 S.W.2d 165 (1928) ; Richmond v. Southern Pacific Co., 41 Ore. 54, 67 Pac. 947 (1902). Contra, Anderson v. Erie R. Co., 223 N.Y. 277, 119 N.E. 557 (1918).

27 See, e.g., Northern Pacific Railway Co. v. Adams, 192 U.S. 440 (1904); Buckley v. Bangor \& A.R. Co., 113 Me. 164, 93 Atl. 65 (1915) ; Quimby v. Boston \& M. R. Co., 150 Mass. 365, 23 N.E. 205 (1890). Cf. Walther v. Southera Pacific Co., 159 Cal. 769, 116 Pac. 51 (1911) (stating that the release from hability for neghigence is valid where the passenger is riding on a pass but holding that CAL. CIv. CODE $\$ 2175$ nevertheless apphed where there was a finding of gross negligence); Donnelly v. Southern Pacific Co., 18 Cal.2d 863, 118 P.2d 465 (1941) (applying federal law, held the exemption valid even as to what would be considered gross negligence in California).

28 Northern Pacific Railway Co. v. Adams, 192 U.S. 440 (1904); Duncan v. Maine Cent. R. Co., 113 Fed. 508 (D. Me. 1902); Note, 37 Conum. L. REv. 248 (1937).

20 New York Cent. R. Co. v. Long Island R. Co., 57 F.2d 144 (2d Cir. 1932).

30 Stephens v. Southern Pacific Co., 109 Cal. 86, 41 Pac. 783 (1895) ; Blitch v. Central of Georgia Ry. Co., 122 Ga. 711, 50 S.E. 945 (1905) ; Pettit Grain \& Potato Co. v. Northern Pac. Ry. Co., 227 Minn. 225, 35 N.W.2d 127 (1948).

31 Mann v. Pere Marquette Railroad Co., 135 Mich. 210, 97 N.W. 721 (1903); Richmond v. New York, N.H. \& H. R. Co., 26 R.I. 225, 58 Atl. 767 (1904). 
for a shipper, ${ }^{31}$ and where it contracts to transport a circus, ${ }^{32}$ the exemption clause is upheld.

\section{Exculpation in Other Fields of Unequal Bargaining Position}

This basic attitude against exemption contracts where there is an unequal bargaining position has been extended into other fields. Public utilities, which may readily exert quasi-economic and domestic compulsion upon the homeowner, are not allowed to contract away their liability for negligence. ${ }^{33}$ The employer cannot relieve himself as to his employees from the consequences of his negligent acts or those for which he is held to be responsible through the principle of respondeat superior. ${ }^{34}$ The unequal bargaining position between employer and his individual employee and the economic fact that the supply of workers generally exceeds the demand are cogent reasons for voiding the contract. Innkeepers, traditionally held to a high standard of care because of their public employment, may not rely upon a release contract. ${ }^{35}$ Telegraph companies similarly are not allowed to exempt themselves from liability ${ }^{36}$ though in California ${ }^{37}$ and a minority of jurisdictions ${ }^{38}$ the company may limit its liability to a specified sum if the sender does not order the message to be repeated. ${ }^{39}$

32 Coup v. Wabash, St. L. \& P. Ry. Co., 56 Mich. 111, 22 N.W. 215 (1885). Cf. Santa Fe, Prescott \& Phoenix Railway Co. v. Grant Brothers Construction Co., 228 U.S. 177 (1913).

33 Denver Consol. Electric Co. v. Lawrence, 31 Colo. 301, 73 Pac. 39 (1903); Collins v. Virginia Power \& Electric Co., 204 N.C. 320, 168 S.E. 500 (1933); Oklahoma Natural Gas Co. v. Appel, 266 P.2d 442 (Okla. 1954) ; Reeder v. Western Gas \& Power Co., 42 Wash.2d 542, 256 P.2d 825 (1953).

34 Federal Employers' Liability Act, 35 StaT. 65 (1908), 45 U.S.C. \& 55 (1952); CAL. LAB. CoDE $\$ 2801$; Robinet v. Hawks, 200 Cal. 265, 252 Pac. 1045 (1927); Hughes v. Warman Steel Casting Co., 174 Cal. 556, 163 Pac. 885 (1917) ; Hackelberry v. Sherlock Land \& Cattle Co., 39 Cal. App. 764, 180 Pac. 37 (1919); Johnston v. Fargo, 184 N.X. 379, 77 N.E. 388 (1906); Pittsburgh, C., C. \& St. L. Ry. Co. v. Kinney, 95 Ohio St. 64, 115 N.E. 505 (1916).

35 Oklahoma City Hotel Co. v. Levine, 189 Okla. 331, 116 P.2d 997 (1941); Maxwell Operating Co. v. Harper, 138 Tenn. 640, 200 S.W. 515 (1918). In California it was formerly held that the innkeeper was liable as an insurer. Fay v. The Pacific Improvement $\mathrm{Co} ., 93 \mathrm{Cal}$. 253, 26 Pac. 1099 (1892). CAL. CIv. CoDE $\$ 1859$ now provides, however, that the innkeeper's liability is that of a depositary for hire and is limited to a specified amount unless he consents in writing with the guest to assume a greater liability. Gardner v. Jonathan Club, $35 \mathrm{Cal} .2 \mathrm{~d}$ 343, 217 P.2d 961 (1950). See Hirsch, Limited Liability of Innkeepers Under Statutory Regulations, 76 U. PA. L. REv. 272 (1928).

36 Bowman \& Bull Co. v. Postal Telegraph-Cable Co., 290 Ill. 155, 124 N.E. 851 (1919); Markley v. Western Union Telegraph Co., 144 Iowa 105, 122 N.W. 136 (1909); Fox v. Postal Telegraph-Cable Co., 138 Wis. 648, 120 N.W. 399 (1909).

37 Coit v. Western Union Telegraph Co., 130 Cal. 657, 63 Pac. 83 (1900); Redington v. Pacific Postal Telegraph Co., 107 Cal. 317, 40 Pac. 432 (1895) ; Hart v. Western Union Telegraph Co., 66 Cal. 579, 6 Pac. 637 (1885). But see Union Construction Co. v. Western Union Telegraph Co., 163 Cal. 298, 125 Pac. 242 (1912), criticizing the rule of these cases.

38 Postal Telegraph-Cable Co. v. Warren-Godwin Lumber Co., 251 U.S. 27 (1919) ; Halsted v. Postal Telegraph-Cable Co, 193 N.Y. 293, 85 N.E. 1078 (1908). Contra, Western Union Telegraph Co. v. Chamblee, 122 Ala. 428, 25 So. 232 (1899) ; Des Arc Oil Mill v. Western Union Telegraph Co., 132 Ark. 335, 201 S.W. 273 (1918) ; Bowman \& Bull Co. v. Postal TelegraphCable Co., 290 IIl. 155, 124 N.E. 851 (1919).

39 In Coit v. Western Union Telegraph Co., 130 Cal. 657, 63 Pac. 83 (1900), the court extended this rule so as to limit recovery by the addressee, saying that the sender was his agent in sending the telegrain and that the addressee's action rested not in tort but in contract where it was held that he was bound by the contract terms. 
The release contract between landlord and tenant is generally held to be solely a matter of private interest and therefore valid. ${ }^{40}$ The two parties deal with each other on relatively equal footing, and frequently the tenant receives a lower rent in consideration for the absence of protection. On the other hand, where the individual has to deal with a housing authority the courts have recognized the lack of equality and have refused to enforce the contract. ${ }^{41}$ In cases which have appeared particularly harsh the courts have seized upon the technique of strict construction in holding the lessor liable to the lessee. ${ }^{42}$

It is contrary to public policy for bailees whose services are practically indispensable to the public to be permitted to use their favorable position to impose oppressive ternis upon those seeking their services. ${ }^{43}$ Thus, it is necessary to distinguish professional bailees, who are regularly engaged in the business of receiving goods from the public, from ordinary bailees, who contract on an individual basis and who assume this status incidentally to their principal course of business. Contracts relieving warehousemen, ${ }^{44}$ owners of parcel checkrooms, ${ }^{45}$ and garagemen and owners of parking places $^{46}$ from their common law duty of due care are invalid as against public policy. There is a decided split in authority as to whether ordinary bailees may exempt themselves from liability for negligence. ${ }^{47}$ In California it has been broadly stated in dictum that a bailee for hire cannot exculpate himself from his own negligence by contract, ${ }^{48}$ but it appears that this rule should be limited to situations where the bailee owes a duty of public service. Thus, where the bailor, in turning over his automobile for repairs, agreed to assume full responsibility for danages incurred, the court stated that this was a purely private matter between two equal parties. ${ }^{49} \mathrm{The}$ California courts, furthermore, have recognized that an unusual situation may

40 Werner v. Knoll, 89 Cal. App.2d 474, 201 P.2d 45 (1948); Inglis v. Garland, 19 Cal. App.2d 767, 64 P.2d 501 (App. Dep't 1936) ; Kirshenbaum v. General Outdoor Advertising Co., 258 N.Y. 489 , 180 N.E. 245 (1932). But cf. Barkett v. Brucato, 122 Cal. App.2d 264, 264 P.2d 978 (1953) ; Butt v. Bertola, 110 Cal. App.2d 128, 242 P.2d 32 (1952).

41 Housing Authority of Birmingham Dist. v. Morris, 244 Ala. 557, 14 So.2d 527 (1943). Cf. W. \& B. Hosiery Corporation v. Kapplow, 158 Misc. 872, 286 N.X.Supp. 784 (1936). Contra, Manius v. Housing Authority of City of Pittsburgh, $350 \mathrm{~Pa} .512,39$ A.2d 614 (1944). 42 Railton v. Taylor, 20 R.I. 279, 38 AtI. 980 (1897); Simmons v. Pagones, 66 S.D. 296, 282 N.W. 257 (1938).

43 See Annot., 175 A.L.R. 8, 110-44 (1948) ; Note, 35 HARv. L. Rev. 478 (1921).

44 England v. Lyon Fireproof Storage Co., 94 Cal. App. 562, 271 Pac. 532 (1928); Inland Compress Co. v. Simmons, 59 Okla. 287, 159 Pac. 262 (1916). Cf. Dieterle v. Bekin, 143 Cal. 683, 77 Pac. 664 (1904); Taussig v. Bode \& Haslett, 134 Cal. 260, 66 Pac. 259 (1901).

45 Denver Union Terminal Ry. Co. v. Cullinan, 72 Colo. 248, 210 Pac. 602 (1922) (dictum) ; Hotels Statler Co. v. Safier, 103 Ohio St. 638, 134 N.E. 460 (1921).

46 Nagaki v. Stockfleth, 141 Neb. 676, 4 N.W.2d 766 (1942); Scott Auto \& Supply Co. v. McQueen, 111 Okla. 107, 226 Pac. 372 (1924); Pilson v. Tip-Top Auto Co., 67 Ore. 528, 136 Pac. 642 (1913). Frequently the courts find that the ticket including the notice of exemption is intended primarily as a token of identification and hold that the attempted release fails for want of mutual assent. Maynard v. James, 109 Conn. 365, 146 Atl. 614 (1929).

47 See Note, 86 U. PA. L. REv. 772 (1938).

48 Northwestern Mutual Fire Association v. Pacific Wharf \& Storage Co., 187 Cal. 38, 41, 200 Pac. 934, 936 (1921).

40 Nichols v. Hitchcock Motor Co., 22 Cal. App.2d 151, 70 P.2d 654 (1937). 
arise, such as a strike of the professional bailee's employees, which will warrant validation of the exemption contract where the contracting parties enjoy relatively equal bargaining power. ${ }^{50}$ The device of artificial equality in limiting the warehouseman's liability to a specified sum unless the bailor declares the true value is also acknowledged $\mathrm{m}$ California so as to protect the bailee from unreasonable and excessive demands. ${ }^{51}$

\section{Other Reasons for Invalidation}

In addition to the decisive element of unequal bargaining position, the courts have mentioned a number of other factors for holding the defendant liable despite the provisions of the contract. These reasons, lowever, are never given as the sole ground for the decision. They are always offered as supplementary reasons, and consequently it would seem that their usefulness fails when the parties are dealing on an equal basis.

The Court in New York Central Railroad Co.v. Lockwood ${ }^{52}$ stated that where the carrier stipulates not to be bound to exercise care and diligence, it seeks to put off "the essential duties of its employment and to assert that it may do so seems almost a contradition in terms." "W3 Where public safety has been involved, the courts on occasion have declared that the exemption contract was invalid because of the existence of a duty in tort over and above the contractual obligation. ${ }^{54}$ Tort duties are imposed by law to protect the interest of society in freedom from various kinds of harm. They are grounded basically upon social policy and not upon the will or intention of the parties. ${ }^{55}$ The duty of ordinary care, therefore, does not arise out of the contract. It is imposed by law upon those who by virtue of their superior bargaining position enter into relationships of public interest. It is thus an incident of the relationship rather than of the contract. ${ }^{56}$ Support for invalidating the exculpatory clause may be found in the analogous cases of contracts to perform an illegal act and consent to the commission of a crime. ${ }^{57}$ The maxim of volenti non fit injuria must indeed be tempered by an investigation into the interests of society, for public policy against criminal or illegal action will frequently invalidate the consent. The analogy of the contract providing for liquidated damages, on the other hand, would appear to be a suitable tool for the party seeking to enforce the provision limiting liability to a specified sum.

${ }_{50}$ Northwestern Mutual Fire Association v. Pacific Wharf \& Storage Co., 187 Cal. 38, 200 Pac. 934 (1921).

51 George v. Bekins Van \& Storage Co., 33 Cal.2d 834, 205 P.2d 1037 (1949); Page v. Ace Van \& Storage Co., 87 Cal. App.2d 294, 196 P.2d 816 (1948); McMullin v. Lyon Fireproof Storage Co., 74 Cal. App. 87, 239 Pac. 422 (1925).

52 New York Central Railroad Co. v. Lockwood, 84 U.S. (17 Wall.) 357 (1873).

53 Id. at 378.

54 Otis Elevator Co. v. Maryland Casualty Co., 75 Colo. 99, 33 P.2d 974 (1934); James Quirk Milling Co. v. Minneapolis \& St. L. R. Co., 98 Minn. 22, 107 N.W. 742 (1906).

65 PROSSER, TORTs 478 (2d ed. 1955).

56 Id. at 481 .

${ }^{67}$ See Note, 36 CoLuMr. L. REv. 994 (1936). Contracts indemnifying against non-willful torts, which are generally upheld, may be distinguished on the basis that they do not deprive anyone of his right but simply effect a change in the person who ultimately has to pay the damages. 
It has been held that the performance of a duty imposed by law is not valid consideration and that, accordingly, the exemption contract fails for lack of consideration..$^{58}$ Where the party seeking exculpation is under a legal obligation to the public to perform his services with ordinary care, certainly his agreeing to do these services in exchange for the release clause is neither a detriment to him nor is it a benefit to the other contracting party. ${ }^{59}$

The presence of complete control over the object of the contract by the defendant has been mentioned as a useful basis for determining liability. ${ }^{.0}$ Where the defendant has complete control the plaintiff is not in a position to protect himself, for it rests entirely in the hands of the defendant whether the job is to be safely completed. A pilot who guides ships through treacherous harbors may validly contract away his liability for negligence. ${ }^{01}$ In this situation the vessel is propelled on its own power and the pilot is at all times during the operation under the orders of the ship's captain. In the Bisso case, on the other hand, it should be noticed that the barge was a completely dead tow and entirely under the control and management of the tugboat.

The necessity of protecting persons and property from injury has also been stressed particularly in carrier cases. ${ }^{2}$ The courts, as in the Bisso case, have often declared that outlawing the contract will result in discouraging negligence. This theory is based on the premise that the fear of being held liable for damages will cause one to be more careful in his dealings with others. ${ }^{63}$ While there may be much economic truth behind this reasoning, it should be noted that the courts will uphold indemnity and insurance contracts which remove the possibility of pecuniary loss to the negligent party. ${ }^{64}$

\section{Conclusion}

The exemption contract is undoubtedly a useful device to protect business concerns from flimsy or trumped-up charges of negligence. It should be recognized, however, that certain losses are a proper expense of doing business. The large business concern is better able to bear such losses and

58 Hiroshima v. Bank of Italy, 78 Cal. App. 362, 248 Pac. 947 (1926), discussed in Note, 15 Cartr. L. Rev. 46 (1926); George v. Chicago R.I. \& P. Ry. Co., 214 Mo. 551, 113 S.W. 1099 (1907).

59 See 1 Wituston, Contracts $\$ 132$ (rev. ed. 1936).

60 Stevens v. The White City, 285 U.S. 195 (1932); Clarke v. Ames, 267 Mass. 44, 165 N.E. 696 (1929).

61 Sun Oil Co. v. Dalzell Towing Co., 287 U.S. 291 (1932).

62 The court, in applying this reason to the particular case, should consider both the possibility and extent of injury as well as the nature of the acts encouraged in case the clause is upheld. It is clear that a contract to release a party from his liability for gross neghigence would be particularly obnoxious from this point of view and contrary to public policy. See RestateMENT, CONTRACTS $\$ 574$ (1932).

03 The fear of losing business and succumbing to the pressure of competition is also a factor in encouraging due care, but it should be noted that the companies herein involved quite often enjoy a quasi-monopolistic position.

64 See Annot., 175 A.L.R. 8, 20-29 (1948). 
can distribute them through prices, rates, or liability insurance to the public. ${ }^{* 5}$ Thus, whenever the relative bargaining position is such that the individual is totally unable to assert a free choice in the making of the contract, the courts very likely will say that an interest of the public is involved and refuse to enforce the exculpatory provision. In determining the existence of a public duty, the courts will consider the iniportance of the service to the individual's physical or economic welfare and the presence and extent of competition as bearing upon the individual's ability to exercise his own volition. The nujority in the Bisso case apparently was convinced that sufficient monopolistic elements were present in that situation to warrant invalidating the contract. It is submitted that when these elements are not present the court should respect the clear intent of the parties and observe the sanctity and freedon of contract.

Robert A. Seligson*

6r See generally, EHREnzWEIg, Negugence Without FaUtit (1951).

* Member, Second-Year Class. 